\title{
Synthesis And Characterization Of
} $\mathrm{Fe}^{0} @$ Chitosan/Cellulose Green Nanocomposite As Advanced Carrier For Ibuprofen Drug; Loading And Release Properties

\author{
Fatma A. El Kashief \\ Beni-Suef University \\ Jong Seong Khim \\ Seoul National University \\ Jamaan S. Ajarem \\ King Saud University \\ Ahmed A. Allam \\ Beni-Suef University \\ Gasem M. Abu-Taweel \\ Jazan University
}

Mostafa Abukhadra ( $\sim$ Abukhadra89@Science.bsu.edu.eg )

Beni-Suef University https://orcid.org/0000-0001-5404-7996

\section{Research Article}

Keywords: Zero-valent iron, Chitosan, Cellulose, Green nanocomposite, Ibuprofen carrier

Posted Date: March 3rd, 2022

DOI: https://doi.org/10.21203/rs.3.rs-1382820/v1

License: (c) (1) This work is licensed under a Creative Commons Attribution 4.0 International License. Read Full License 


\section{Abstract}

Green nanocomposite of $\mathrm{Fe}^{0} @$ chitosan/cellulose ( $\left.\mathrm{Fe}^{0} @ \mathrm{CH} / \mathrm{CS}\right)$ was synthesized utilizing the green extract of khaya senegalensis leaves and sugarcane bagasse as cellulose precursor. The composite was evaluated as an effective carrier for ibuprofen drug (IBF) considering its release and loading properties. The Fe ${ }^{0} @ \mathrm{CH} / \mathrm{CS}$ is of significant IBF loading capacity $(553 \mathrm{mg} / \mathrm{g})$ and the loading behavior can be directed by the values of the experimental variables. The loading of IBF into Fe ${ }^{0} @ \mathrm{CH} / \mathrm{CS}$ is in agreement with the classic Langmuir isotherm $\left(R^{2}>0.95\right)$ and Pseudo-first order kinetic $\left(R^{2}>0.97\right)$. This displays homogenous, physisorption, and a monolayer loading of IBF into $\mathrm{Fe}^{0} @ \mathrm{CH} / \mathrm{CS}$. Based on the findings of the Monolayer model with one energy as advanced isotherm model, the $\mathrm{Fe}^{0} @ \mathrm{CH} / \mathrm{CS}$ structure is of 252.6 $\mathrm{mg} / \mathrm{g}$ active receptors density and each rector was occupied by two or three IBF ions $(n=2.18)$ by multimolecular mechanism. The determined IBF loading energy $(4.81 \mathrm{~kJ} / \mathrm{mol})$ demonstrates the physical loading of the drug by Van-der Waals forces and/or hydrogen bonding. The Fe $\mathrm{e}^{0} \mathrm{CH} / \mathrm{CS}$ structure is of significant release profiles as carrier for IBF which continued up to $260 \mathrm{~h}$ (gastric buffer) and $180 \mathrm{~h}$ (intestinal buffer). The studied release kinetics and the obtained diffusion exponent $(0.58(\mathrm{pH} 1.2)$ and $0.48(\mathrm{pH} 7.4)$ ) reflect the release of IBF from $\mathrm{Fe}^{0} @ \mathrm{CH} / \mathrm{CS}$ by complex diffusion and erosion mechanisms. The cytotoxicity tests declared the safe and biocompatible value of both Fe $\mathrm{e}^{0} \mathrm{CH} / \mathrm{CS}$ and IBF loaded $\mathrm{Fe}^{0} @ \mathrm{CH} / \mathrm{CS}$ on the human bronchial epithelial cells.

\section{Introduction}

Inflammation as a health term refers to the biological responses of the organisms when affected by the different species of infections which commonly resulted in high damage impacts as compared to the essential infects [1, 2]. Several species of drugs were applied as anti-inflammation drugs including ibuprofen, azithromycin, and levofloxacin [3, 4]. Ibuprofen $\left(\mathrm{C}_{13} \mathrm{H}_{18} \mathrm{O}_{2}\right.$; IBF) is considered a long-term nonsteroidal anti-inflammatory and antipyretic drug [5]. It is used for analgesic symptoms of pain and a variety of rheumatoid arthritis and musculoskeletal in addition to its value as medication for acute pain and fever for the children $[5,6]$. The application of IBF suffers from some problems which are related to its low solubility, short half-life, low bioavailability, high permeability, and fast degradation [7]. Moreover, the overdosages are of certain adverse effects including nausea, dyspepsia, and diarrhea in addition to the gastrointestinal toxicity of its chemical structure [8]. It has a significant negative effect on the gastric mucus and reduces its resistance to acidic conditions in addition to its side effects on gastric and mucosal protective agents [9].

The interested researcher did their best to develop a new effective drug delivery system to enhance the release percentage, solubility, stability, bio-distribution properties, and specificity of the drug $[9,10]$. This can reduce its hazardous side effects, improve therapeutic efficiency, and enhance patient compliance [8, $10,11]$. The properties which were recommended for the effective carriers are the significant biocompatibility, chemical inertness, mechanical strength, and high loading capacities in addition to the low fabrication cost $[1,12]$. Therefore, developing enhanced IBF delivering systems to control the released 
percentage and keep the drug concentration at the safe level was recommended strongly in the later periods $[5,9,13]$. Recently several products were assessed for this target as hydroxyapatite, MCM-41, titanium alloy, MOFs, biopolymer-based composites, and montmorillonite $[8,9,13]$.

The natural polymer which can be extracted from the bio-resources as plants (starch, chitosan, and cellulose) and animal (collagen, albumin, and gelatin) were studied extensively as natural biopolymers of significant medical and health applications $[14,15,16]$. Such polymers are of excellent biocompatibility, chemical safety, availability, reactivity, and chemical affinities for the organic structures of the drug [12, $17,18]$. Among such biopolymers, cellulose and chitosan attracted great attention as promising materials in several industrial and medical industries $[9,19]$. Cellulose is a known type of natural polysaccharide biopolymer composed structurally of anhydroglucose rings which are connected chemically with each other by b-1, 4 glycoside bonds $[12,20]$. Cellulose is of significant availability as it is a valuable component in numerous green plants, agricultural wastes, and biomasses which can be extracted by facile and low-cost methods [21]. Technically, cellulosic materials are low-cost, non-toxic, stable, biocompatible, highly reactive, biodegradable, and highly heat resistant materials $[17,19,22]$. Additionally, it exhibits high chemical flexibility to be modified or integrated into numerous varieties of composites either with organic or inorganic materials [17, 23].

Chitosan is also is a well-known biopolymer that is an essential component for numerous environmental, medical, and pharmaceutical applications especially as a drug carrier $[9,15,18]$. Chitosan is polyaminosaccharide polymer that is of several technical advantages and can be produced easily from the chitin component in different biogenic sources [18]. Technically, the chitosan chains are of high safety, high bioactivity, and biodegradability in addition to their high mechanical and adsorption properties $[9,24]$. The predicted integration between cellulose and chitosan in a composite can result in a hybrid structure of high reactivity, enhanced morphology, high loading capacity, and controlled loading behavior. Additionally, the possible functionalization of such a hybrid structure with metal oxide of green properties can induce the impact of the used drug and the loading capacity of the final structure.

Among the green fabricated metals and metal oxides, zero-valent iron $\left(\mathrm{Fe}^{0}\right)$ and $\mathrm{Fe}_{2} \mathrm{O}_{3} \mathrm{NPs}$ were investigated as innovative materials for biomedical industries, drug delivery systems, tissue repair applications, and hyperthermia [23, 25]. Such nanoparticles are of good dispersion properties, high stability, significant biocompatibility, high biodegradability, and nontoxicity $[25,26]$. Therefore, the presented study involved a novel synthesis of cellulose, chitosan, and $\mathrm{Fe}^{0}$ heterostructure ( $\left.\mathrm{Fe}{ }^{0} @ \mathrm{CH} / \mathrm{CS}\right)$ green extract of khaya senegalensis leaves and sugarcane bagasse as cellulose precursor. The $\mathrm{Fe}^{0} @ \mathrm{CH} / \mathrm{CS}$ structure was characterized as a potential carrier for IBF drug of enhanced loading and release properties. The loading studies involved investigation for the effect of the experimental variables as well as the mechanism considering the kinetic, classic isotherm, advanced equilibrium, and thermodynamic studies. Also, the release profiles were addressed for about $260 \mathrm{~h}$ at different release buffers and the release mechanism was studied based on the kinetic release modeling. 


\section{Experimental Work \\ 2.1. Materials}

The studied raw cellulose was extracted from sugarcane bagasse. Sodium hydroxide pellets ( $>98 \%)$, potassium hydroxide pellets $(>85 \%)$, sulfuric acid $(98 \%)$, acetic anhydride $(98 \%)$, and sodium hypochlorite (5\%) (Sigma-Aldrich Egypt) were used during the extraction of cellulose. Chitosan powder was delivered a commercial polymer (MW 120,000; 85\%) and glacial acetic acid (Sigma- Aldrich Egypt, $99.8 \%$ ) was used as a solvent for chitosan. Ferric chloride (\%) and liquid extract of khaya senegalensis leaves were used during the synthesis of green zero-valent iron $\left(\mathrm{Fe}^{0}\right)$. Ibuprofen drug ( $98 \%$ purity; SigmaAldrich Egypt) was applied during the loading and release tests.

\subsection{Synthesis of the carrier}

\subsubsection{Extraction of cellulose}

The commercial sugarcane bagasse (SB) was cut into small pieces and dried in an open environment. After that, the sample was ground using a home hand blender to be within the size range from $50 \mu \mathrm{m}$ to $100 \mu \mathrm{m}$. Then, $500 \mathrm{~g}$ of SB was immersed within $\mathrm{NaOH}$ solution $(18 \mathrm{~N})$ for $2 \mathrm{~h}$ at $170^{\circ} \mathrm{C}$ as starting step. This was followed with bleaching step using $\mathrm{NaClO}_{2} / \mathrm{CH}_{3} \mathrm{COOOH}$ mixture $(5 \% \mathrm{w} / \mathrm{v})$ at $70^{\circ} \mathrm{C}$ and $\mathrm{pH} 5$ for an additional $120 \mathrm{~min}$. Then the bleached product was neutralized by washing and transferred treated with $\mathrm{KOH}$ solution $(4 \%(\mathrm{w} / \mathrm{v}))$ for $1 \mathrm{~h}$ at $80^{\circ} \mathrm{C}$ to get rid of hemicellulose. The alkaline treated product was neutralized and bleached again $\left(5 \% \mathrm{NaClO}_{2}+\mathrm{CH}_{3} \mathrm{COOH}\right)$ at $70^{\circ} \mathrm{C}$ for $2 \mathrm{~h}$. This was followed with acid leaching step $\left(30 \% \mathrm{H}_{2} \mathrm{SO}_{4}\right)$ at $45^{\circ} \mathrm{C}$ for $1 \mathrm{~h}$ in the existence of the sonication waves producing cellulose enrich fibers.

\subsubsection{Chitosan/cellulose composite (CH/CS)}

The synthesis of chitosan/cellulose composite was performed by facile dispersion of the extracted cellulose fibrous $(5 \mathrm{~g})$ within a chitosan solution. The chitosan gel was prepared by dissolving $5 \mathrm{~g}$ of chitosan powder within diluted acetic acid $(0.1 \mathrm{M})$. The cellulose/chitosan solution mixture was left for $24 \mathrm{~h}$ under stirring at $500 \mathrm{rpm}$. After that, the resulted hybrid cellulose/chitosan structure was isolated, washed with distilled water, and finally dried for $12 \mathrm{~h}$ at $60^{\circ} \mathrm{C}$.

\subsubsection{Synthesis of Fe ${ }^{0} @$ chitosan/Cellulose nano- composite ( $\left.\mathrm{Fe}^{0} @ \mathrm{CH} / \mathrm{CS}\right)$}

The obtained $\mathrm{CH} / \mathrm{CS}$ particles were ground to be within size range from10 to $25 \mu \mathrm{m}$. After that $3 \mathrm{~g}$ of the $\mathrm{CH} / \mathrm{CS}$ fractions were dispersed within $100 \mathrm{~mL}$ of ferric chloride solution $(3 \mathrm{M})$. As a parallel step, the green extract was produced by boiling the Khaya senegalensis leaves ( $20 \mathrm{~g}$ in $100 \mathrm{~mL}$ water) for $5 \mathrm{~min}$ and after cool down to room temperature was added to the ferric chloride mixture in the presence of $\mathrm{CH} / \mathrm{CS}$ fractions. The final mixture was left under string for $48 \mathrm{~h}$ at room conditions before extracting the 
solid by filtration. The extracted solids were washed with distilled water carefully and dried at $60^{\circ} \mathrm{C}$ overnight to be applied in the next steps.

\subsection{Characterization techniques:}

The crystalline properties were addressed considering the XRD patterns of the chitosan and cellulose components and the synthetic composite $\left(\mathrm{Fe}^{0} @ \mathrm{CH} / \mathrm{CS}\right)$ using X-ray diffractometer (PANalytical (Empyrean)). The chemical composition and the structural functional groups were addressed considering the FT-IR spectra (Fourier Transform Infrared spectrometer (FTIR - 8400S)). The morphology of the produced structure and its internal properties were assessed considering the SEM (Scanning-Electron Microscope (Gemini, Zeiss-Ultra 55)) and HRTEM (Transmission-Electron Microscope (JEOL-JEM2100)) images, respectively. The surface area of the $\mathrm{Fe}^{0} @ \mathrm{CH} / \mathrm{CS}$ composite as well as its porous structure was studied based on its measured $\mathrm{N}_{2}$ adsorption/desorption curve using Beckman Coulter surface area analyzer (SA3100 type).

\section{4. $\mathrm{Fe}^{0} @ \mathrm{CH} / \mathrm{CS}$ as carriers for Ibuprofen drug 2.4.1. The loading properties}

The properties of $\mathrm{Fe}^{0} @ \mathrm{CH} / \mathrm{CS}$ were assessed based on several experimental variables including the loading $\mathrm{pH}$ ( $\mathrm{pH} 2$ up to $\mathrm{pH} 8$ ) interval (1 h up to $24 \mathrm{~h}$ ), drug concentration (100 up to $900 \mathrm{mg} / \mathrm{L}$ ), and the $\mathrm{Fe}^{0} @ \mathrm{CH} / \mathrm{CS}$ dosage (20 mg up to $100 \mathrm{mg}$ ). The homogenization between the drug solutions and the $\mathrm{Fe}^{0} @ \mathrm{CH} / \mathrm{CS}$ particles was conducted using a vortex rotator. After the equilibration interval of each loading test, the $\mathrm{Fe}^{0} @ \mathrm{CH} / \mathrm{CS}$ particles were separated by filtration using Whitman filter paper and the filtrate samples were collected to detect the rest of IBF in the solutions. The remaining concentrations of IBF after the loading tests were measured by UV-Vis spectrophotometer $(\lambda(\max )=222 \mathrm{~nm})$ to calculate the loading capacity based on Eq. 1 [21]. All the tests were completed in triplicate form and the evaluated results were inserted as average values with a standard deviation of less than $3.2 \%$.

$$
\text { Loadeddrug }(\mathrm{mg} / \mathrm{g})=\frac{\text { (Initialconcentration }- \text { Residualconcentration)Xsolventvolume }}{\text { Carrierweight }}
$$

\subsubsection{In-vitro release studies}

The release profile of $\mathrm{Fe}^{0} @ \mathrm{CH} / \mathrm{CS}$ as a carrier for IBF was studied using two types of buffers of different $\mathrm{pH}$ (pH 1.2 (Gastric fluid) and pH 7.4 (Intestinal fluid)). The release tests were conducted by mixing certain quantities of IBF-loaded Fe $\mathrm{C}^{0} @ \mathrm{CH} / \mathrm{CS}(100 \mathrm{mg} / \mathrm{g})$ within $500 \mathrm{~mL}$ of the studied buffers for a total release interval of $120 \mathrm{~h}$. The homogenization process between the IBF-loaded Fe $\mathrm{C}^{0} \mathrm{CH} / \mathrm{CS}$ particles and the buffers was accomplished by the DISTEK dissolution apparatus considering the rotating speed of the vessels at $200 \mathrm{rpm}$. After that, regular samples $(5 \mathrm{~mL})$ were extracted from the buffers at regular intervals to determine the diffused IBF molecules using a UV-Vis spectrophotometer $(\lambda(\max )=222 \mathrm{~nm})$. Then the 
extracted samples were re-incorporated again into the bulk buffers to preserve the volume during the release process. The measured concentrations of the diffused IBF were applied to calculate the release percentages according to Eq. 2 considering the average values of the tests as triplicate tests with a standard deviation less than $2.8 \%$.

$$
\text { Drugrelease }(\%)=\frac{\text { TheamountofReleasedIBF }}{\text { AmountofloadedIBF }} \mathrm{X} 100(2)
$$

\subsection{In Vitro Cytotoxicity}

The cytotoxicity properties of Fe ${ }^{0} @ \mathrm{CH} / \mathrm{CS}$ and IBF-loaded Fe $\mathrm{e}^{0} @ \mathrm{CH} / \mathrm{CS}$ were studied considering their effect on the human bronchial epithelial cells (NL20) (American Type Culture Collection (ATCC). This was accomplished to assess the value of the product during the treatment and reduction of the cytokine effects within the bronchial epithelial cells. The test was conducted by immersion of the cell lines within Ham's F12 medium of different components (hydrocortisone $\left(500 \mathrm{ng} / \mathrm{mL}^{-1}\right)$, glutamine $(2 \mathrm{mML})$, epidermal growth factor $\left(10 \mathrm{ng} / \mathrm{mL}^{-1}\right)$, amino acid $(0.1 \mathrm{mM})$, transferrin $\left(1 \mathrm{mg} / \mathrm{mL}^{-1}\right), 5 \mathrm{mg} / \mathrm{mL}^{-1}$ insulin, FBS (4\%), and $5 \mathrm{mg} / \mathrm{mL}^{-1}$ insulin,). The studied cells after that were seeded for $24 \mathrm{~h}$ using 24 -well culture plates and then incubated for another $24 \mathrm{~h}$ within the growth medium without serum. Then, regular dosages of Fe ${ }^{0} @ \mathrm{CH} / \mathrm{CS}$ and IBF-loaded Fe $\mathrm{e}^{0} @ \mathrm{CH} / \mathrm{CS}$ were mixed with the media for an incubation period of $24 \mathrm{~h}$. This was followed by the removal step for the used media and the treated cells were incubated again in fresh media for $4 \mathrm{~h}$ in the existence of resazurin (5\%). As a final step, the cell viability at the different dosages was determined based on the fluorescence signals which were obtained after the addition of the dye considering the measurement conditions at $590 \mathrm{~nm}$ emission and $544 \mathrm{~nm}$ excitation. The detected variations in the measured values were used to determine the relative values of cell viability considering the value of the fresh cells as $100 \%$.

\section{Results And Discussion}

\subsection{Characterization of the carrier 3.1.1. XRD analysis}

The structural properties of the synthetic Fe ${ }^{0} @ \mathrm{CH} / \mathrm{CS}$ were evaluated considering its XRD pattern in comparison with the patterns of cellulose and chitosan (Fig. 1). The cellulose substrate was recognized as crystalline cellulose with its common peaks at 2 Theta angles of $14.6^{\circ}(1 \overline{1} 0), 16.6^{\circ}(110), 22.7^{\circ}(200)$, and $34.6^{\circ}$ (004)) JCPDS card no 00-056-1718) (Fig. 1A). The integrated chitosan as a single component exhibits the common peaks of semi-crystalline chitosan $\left(9.91^{\circ}\right.$ and $\left.20.22^{\circ}\right)$ [18] (Fig. 1B). The obtained pattern of $\mathrm{Fe}^{0} @ \mathrm{CH} / \mathrm{CS}$ still shows reduced humps for the cellulose identification peaks and wellrecognized peaks at about $44.8^{\circ}(110)$ and $65.3^{\circ}(200)$ which characterize the crystalline zero-valent iron 
(JCPDS: 006-0696) (Fig. 1C). Additionally, a single reduced peak for magnetite was detected at about $56.2^{\circ}$ (JCPDS no. 19-0629) reflecting partial oxidation of the $\mathrm{Fe}^{0}$ particles and suggesting an effective role for the polymers matrix in reducing the oxidation process (Fig. 1C).

\subsubsection{FT-IR analysis}

The FT-IR spectra of Fe ${ }^{0} @ \mathrm{CH} / \mathrm{CS}$ and IBF-loaded Fe ${ }^{0} @ \mathrm{CH} / \mathrm{CS}$ were assessed in comparison with the characteristic spectra of cellulose and chitosan (Fig. 2). For the cellulose, the main identification bands of its chemical groups were detected at $3450 \mathrm{~cm}^{-1}$ (OH groups), 2914 and $1367 \mathrm{~cm}^{-1}$ (-CH bearing groups), $1630 \mathrm{~cm}^{-1}$ (adsorbed water molecules), $1057 \mathrm{~cm}^{-1}$ (-C-O-C of pyranose ring), and $897 \mathrm{~cm}^{-1}$ ( $\beta$-glycosidic linkages) [28] (Fig. 2A). For chitosan as separated components, the spectrum demonstrates the existence its chemical groups including $\mathrm{O}-\mathrm{H}$ and or $\mathrm{N}-\mathrm{H}\left(3423 \mathrm{~cm}^{-1}\right),-\mathrm{CH}\left(2915 \mathrm{~cm}^{-1}\right), \mathrm{C}=\mathrm{O}\left(1637.2 \mathrm{~cm}^{-1}\right), \mathrm{C}-\mathrm{N}$ group $\left(1402 \mathrm{~cm}^{-1}\right)$, and C-O $\left(1040 \mathrm{~cm}^{-1}\right)$ [18] (Fig. 2B).

The spectrum of $\mathrm{Fe}^{0} @ \mathrm{CH} / \mathrm{CS}$ shows intensification in the observed bands around $3390 \mathrm{~cm}^{-1}, 2900 \mathrm{~cm}^{-}$ $1,1630 \mathrm{~cm}^{-1}, 1400 \mathrm{~cm}^{-1}$, and $1045 \mathrm{~cm}^{-1}$ as compared to the reported bands for cellulose and chitosan (Fig. 2C). This demonstrates the overlap between the chemical groups of the two integrated organic components. Additionally, the considerable shifting in the positions of these bands suggested chemical interaction between chemical groups of cellulose and chitosan. The $\beta$-glycosidic linkage of cellulose was identified in the composite by a reduced and deviated band at $787.7 \mathrm{~cm}^{-1}$ (Fig. $2 \mathrm{C}$ ). The detected small band at $669 \mathrm{~cm}^{-1}$ and $560 \mathrm{~cm}^{-1}$ (Fe-O) declare the partial oxidation of the $\mathrm{Fe}^{0}$ iron particles which is in agreement with the XRD findings [25, 26] (Fig. 2C).

The inspected spectrum of the IBF loaded sample declared remarkable changes in both positions and intensities of the $\mathrm{Fe}^{0} @ \mathrm{CH} / \mathrm{CS}$ reported bands suggesting significant interaction with the chemical structure of the drug (Fig. 2D). Additionally, several new bands were detected related to the carbonyl group $\left(1760 \mathrm{~cm}^{-1}\right)$ and the aromatic ring $\left(700 \mathrm{~cm}^{-1}-1500 \mathrm{~cm}^{-1}\right)$ of the IBFdrug [29] (Fig. 2D). Such observations confirm the effective entrapping of the IBF drug into $\mathrm{Fe}^{0} @ \mathrm{CH} / \mathrm{CS}$ composite as delivery system.

\subsubsection{SEM and HRTEM analyses}

The SEM images of the chitosan/cellulose composite ( $\mathrm{CH} / \mathrm{CS})$ reflect the presence of the composite as tabular or cylindrical grains of smooth surface (Fig. 3A). The present grains are commonly agglomerated with each other in irregular forms which might be related to the integrated chitosan which acts as a matrix for the cellulose fibers (Fig. 3B). The HRTEM images confirm the detected morphology of $\mathrm{CH} / \mathrm{CS}$ composite as tabular or rods-like grains (Fig. 3C). The tabular interconnected with each other by the chitosan matrix-forming porous structure (Fig. 3C). For the synthetic Fe ${ }^{0} @ \mathrm{CH} / \mathrm{CS}$ composite, the SEM images demonstrate the decoration of the $\mathrm{CH} / \mathrm{CS}$ tabular grains with numerous micro/nanoparticles of the synthetic green $\mathrm{Fe}^{0}$ particles (Fig. 3D). The same observations were observed clearly in the studied HRTEM images as the tabular particles of $\mathrm{CH} / \mathrm{CS}$ composite were coated with the $\mathrm{Fe}^{0}$ particles (Fig. 3E). 
The previous findings confirm the formation of hybrid structure of chitosan, cellulose, and Fe0 with multifunctional active chemical groups and enhanced morphology.

\subsection{IBF loading properties of $\mathrm{Fe}^{0} @ \mathrm{CH} / \mathrm{CS}$ \\ 3.2.1. Effect of the loading variables \\ 3.2.1.1. Effect of $\mathrm{pH}$ values}

The influence of $\mathrm{pH}$ on the IBF loading capacity of $\mathrm{Fe}^{0} @ \mathrm{CH} / \mathrm{CS}$ was assessed from pH 2 up to 8. The other affecting variables were fixed at $20^{\circ} \mathrm{C}$ as temperature, $400 \mathrm{mg} / \mathrm{L}$ as IBF concentration, $50 \mathrm{~mL}$ as IBF solution volume, $20 \mathrm{mg}$ as carrier dosage, and $24 \mathrm{~h}$ as loading interval (Fig. 4A). The obtained IBF loading trends by $\mathrm{Fe}^{0} @ \mathrm{CH} / \mathrm{CS}$ declare a noticeable enhancement in the determined IBF capacities as the $\mathrm{pH}$ values increased from $\mathrm{pH} 2$ up to $\mathrm{pH} 6$ (Fig. 4A). This was followed by a noticeable declination in the recognized IBF loading capacity for the investigated pH values from pH 6 up to pH 8 (Fig. 4A). The observed faint IBF loading properties of $\mathrm{Fe}^{0} @ \mathrm{CH} / \mathrm{CS}$ at the low pH values were illustrated as a result of the hydrophobic and low solubility nature of the drug at the acidic conditions [30]. Therefore, the increment in the $\mathrm{pH}$ enhances the hydrophilic and solubility behaviors of IBF molecules to be in an ionic form which induces their loading into Fe ${ }^{0} @ \mathrm{CH} / \mathrm{CS}$ structure [9]. Beyond pH 6, the significant deprotonation of the $\mathrm{Fe}^{0} @ \mathrm{CH} / \mathrm{CS}$ effective chemical groups resulted in remarkable electrostatic repulsion with carboxylate groups of IBF which are of negative charges at these conditions [31, 32]. Therefore, $\mathrm{pH} 6$ is the recommended value to attain the best IBF loading capacity $(410 \mathrm{mg} / \mathrm{g})$ by the synthetic $\mathrm{Fe}^{0} @ \mathrm{CH} / \mathrm{CS}$ composite (Fig. 4A).

\subsubsection{Effect of IBF loading interval}

The loading behavior of IBF into Fe $@$ @CH/CS as a function of the experimental interval was followed from $1 \mathrm{~h}$ up to about $24 \mathrm{~h}$. The other affecting variables were fixed at $\mathrm{pH} 6,20^{\circ} \mathrm{C}$ as temperature, 400 $\mathrm{mg} / \mathrm{L}$ as IBF concentration, $20 \mathrm{mg}$ as carrier dosage, and $50 \mathrm{~mL}$ as IBF solution volume (Fig. 4B). Generally, there is a significant enhancement in the actual IBF loading capacities with expanding the tested interval up to $12 \mathrm{~h}(395 \mathrm{mg} / \mathrm{g})$ (Fig. 4B). After that, the determined IBF loading capacity slightly increased and appears to be nearly fixed up to $24 \mathrm{~h}(410 \mathrm{mg} / \mathrm{g})$ displaying an equilibration state (Fig. 4B). The presence of numerous free and active loading receptors on the surface of Fe $0 \mathrm{CH} / \mathrm{CS}$ during the initial loading intervals resulted in a strong increment in the IBF loading capacity at a fast rate [33]. The gradual occupation of the $\mathrm{Fe}^{0} @ \mathrm{CH} / \mathrm{CS}$ free receptors by the adsorbed IBF ions resulted in an observable reduction in the actual loading rate. This can be detected until the full occupation of all the present receptors with the IBF ions which demonstrates the IBF loading equilibration of Fe $0 \mathrm{CH} / \mathrm{CS}$.

\subsubsection{Effect of IBF concentration}

The maximum IBF loading capacity of $\mathrm{Fe}^{0} @ \mathrm{CH} / \mathrm{CS}$ was studied by detecting the loading properties in the existence of different IBF concentrations (100 to 900 mg/L) (Fig. 4C). The other affecting variables were 
fixed at $\mathrm{pH} 6,20^{\circ} \mathrm{C}$ as temperature, $24 \mathrm{~h}$ as loading interval, $20 \mathrm{mg}$ as carrier dosage, and $50 \mathrm{~mL}$ as IBF solution volume. The recognized results display a strong increment in the values with testing the loading properties of $\mathrm{Fe}^{0} @ \mathrm{CH} / \mathrm{CS}$ using high concentrations of IBF up to $700 \mathrm{mg} / \mathrm{L}$ (Fig. 4C). This was reported in the literature as a result of the expected increase in the IBF driving forces with increasing the concentration. This enhances the diffusion properties of the dissolved IBF ions towards the free active loading receptors of $\mathrm{Fe}^{0} @ \mathrm{CH} / \mathrm{CS}$ which in turn improves the actual IBF loading results $[15,34]$. The increase in the tested IBF concentration above $700 \mathrm{mg} / \mathrm{L}$ up to $900 \mathrm{mg} / \mathrm{L}$ is of slight impact on the measured IBF loading capacity of Fe $\mathrm{F}^{0} @ \mathrm{CH} / \mathrm{CS}$ (Fig. 4C). Therefore, the equilibrium concentration during the loading of IBF into $\mathrm{Fe}^{0} @ \mathrm{CH} / \mathrm{CS}$ is $700 \mathrm{mg} / \mathrm{L}$. After the equilibrium concentration, all the active receptors of the $\mathrm{Fe}^{0} @ \mathrm{CH} / \mathrm{CS}$ composite were occupied by the drug and attended its actual maximum capacity ( $526.2 \mathrm{mg} / \mathrm{g})$ (Fig. 4C).

\subsubsection{Effect of $\mathrm{Fe}^{0} @ \mathrm{CH} / \mathrm{CS}$ quantities}

Testing the loading properties of IBF using different quantities of $\mathrm{Fe}^{0} @ \mathrm{CH} / \mathrm{CS}$ was accomplished from 20 $\mathrm{mg}$ up to $100 \mathrm{mg}$ as an essential factor to control the IBF loaded dosages (Fig. 4D). The other affecting variables were fixed at $\mathrm{pH} 6,20^{\circ} \mathrm{C}$ as temperature, $24 \mathrm{~h}$ as loading interval, $400 \mathrm{mg} / \mathrm{L}$ as IBF concentration, and $50 \mathrm{~mL}$ as IBF solution volume. The IBF loading percentages using $\mathrm{Fe}^{0} @ \mathrm{CH} / \mathrm{CS}$ enhanced significantly by $41 \%, 63.4 \%, 82.6 \%, 96.8 \%$, and $100 \%$ with increasing its quantities in the tests by $20 \mathrm{mg}, 40 \mathrm{mg}, 60 \mathrm{mg}, 80 \mathrm{~g}$, and $100 \mathrm{mg}$, respectively (Fig. 4D). This was illustrated as a result of the strong increase in the availability of the $\mathrm{Fe}^{0} @ \mathrm{CH} / \mathrm{CS}$ active loading receptors with increasing its quantity as well as the interaction interface between the drug solution and the composite particles [33].

\subsubsection{Loading mechanism}

\subsubsection{Kinetic studies}

The Intra-Particle diffusion curve in addition to both Pseudo-First and Pseudo-Second order models were studied to illustrate the IBF loading reactions into $\mathrm{Fe}^{0} @ \mathrm{CH} / \mathrm{CS}$ carrier (Table.S1). Considering the observed segments in the Intra-Particle diffusion curve, the IBF loading process into $\mathrm{Fe}^{0} @ \mathrm{CH} / \mathrm{CS}$ involved three essential mechanisms and did not control only by the diffusion behaviour of the drug ions (Fig. 4E). The first segment in the curve reflects the loading of IBF by surficial adsorption mechanism depending on the present free receptor sites on the surface of $\mathrm{Fe}^{0} @ \mathrm{CH} / \mathrm{CS}$ carrier [34] (Fig. 4E). This was followed by another segment which reflects the saturation of the surficial receptors with the IBF ions and the operation of the layered adsorption processes as the dominant loading mechanism [35] (Fig. 4E). The last segment which represents the equilibrium portion of the curve reflects the dominance of molecular association and/or interionic processes as the effective loading mechanisms [36].

Considering the fitting results, the values of both Chi-squared $\left(\mathrm{X}^{2}\right)$ and determination coefficient $\left(\mathrm{R}^{2}\right)$ reflect the operation of the IBF loading reactions into $\mathrm{Fe}^{0} @ \mathrm{CH} / \mathrm{CS}$ according to the kinetic properties of the Pseudo-First order model (PF) (Fig. 4F; Table.1). This suggested controlling impact for the 
physisorption mechanisms during the loading of IBF ions into Fe ${ }^{0} @ \mathrm{CH} / \mathrm{CS}$ carrier. However, the reported good agreement with Pseudo-Second order kinetics demonstrates considerable effects for some chemisorption mechanisms during the loading process as chemical complexation (Fig. 4F; Table.1) [36, 37].

Table.1. The theoretical parameters of the studied the kinetic models, the equilibrium models, Van't Hof formula, and the release kinetic models. 


\begin{tabular}{|c|c|c|}
\hline Model & Parameters & \\
\hline \multirow[t]{5}{*}{ Pseudo-first-order } & $K_{1}\left(\min ^{-1}(\right.$ & 0.291 \\
\hline & $\mathrm{qe}_{\text {(Cal) }}(\mathrm{mg} / \mathrm{g})$ & 409.6 \\
\hline & & 0.99 \\
\hline & $\mathbf{R}^{2}$ & 0.18 \\
\hline & $x^{2}$ & \\
\hline \multirow[t]{4}{*}{ Pseudo-second-order } & $\mathrm{k}_{2}\left(\mathrm{~g} \mathrm{mg}^{-1} \mathrm{~min}^{-1}\right)$ & $5.12 \times 10^{-4}$ \\
\hline & $\mathrm{qe}_{(\mathrm{Cal})}(\mathrm{mg} / \mathrm{g})$ & 463 \\
\hline & $\mathbf{R}^{2}$ & 0.96 \\
\hline & $x^{2}$ & 1.12 \\
\hline \multicolumn{3}{|l|}{ Isotherm models } \\
\hline \multirow[t]{6}{*}{ Langmuir } & $q_{\max (m g / g)}$ & 544.5 \\
\hline & $\mathrm{b}(\mathrm{L} / \mathrm{mg})$ & 0.0026 \\
\hline & $\mathbf{R}^{2}$ & 0.94 \\
\hline & $x^{2}$ & 2.31 \\
\hline & & $0.04-0.79$ \\
\hline & $\mathrm{K}_{\mathrm{L}}$ & \\
\hline \multirow[t]{4}{*}{ Freundlich } & $1 / n$ & 0.623 \\
\hline & $k_{F}(m g / g)$ & 10.66 \\
\hline & $\mathbf{R}^{2}$ & 0.88 \\
\hline & $x^{2}$ & 3.67 \\
\hline \multirow[t]{6}{*}{ D-R model } & $\beta\left(\mathrm{mol}^{2} / \mathrm{KJ}^{2}\right)$ & 0.0096 \\
\hline & $q_{m}(m g / g)$ & 517.5 \\
\hline & $R^{2}$ & 0.96 \\
\hline & & 1.89 \\
\hline & $\mathrm{X}^{2}$ & 7.2 \\
\hline & $\mathrm{E}(\mathrm{KJ} / \mathrm{mol})$ & \\
\hline
\end{tabular}




\begin{tabular}{|c|c|c|}
\hline Model & \multicolumn{2}{|l|}{ Parameters } \\
\hline \multirow[t]{4}{*}{ Monolayer model of one energy } & $\mathbf{n}$ & 2.18 \\
\hline & $\mathrm{Nm}(\mathrm{mg} / \mathrm{g})$ & 252.6 \\
\hline & $Q_{\text {(sat) }}(\mathrm{mg} / \mathrm{g})$ & 553 \\
\hline & $\Delta \mathrm{E}(\mathrm{kJ} / \mathrm{mol})$ & 4.81 \\
\hline \multicolumn{3}{|l|}{ Thermodynamics } \\
\hline \multirow[t]{5}{*}{$\Delta \mathrm{G}^{\circ}\left(\mathrm{kJ} \mathrm{mol}^{-1}\right)$} & 293.15 & -15.94 \\
\hline & 303.15 & -16.40 \\
\hline & 313.15 & -16.78 \\
\hline & 323.15 & -17.07 \\
\hline & 333.15 & -17.43 \\
\hline$\Delta \mathrm{H}^{\circ}\left(\mathrm{kJ} \mathrm{mol}^{-1}\right)$ & & -5.28 \\
\hline$\Delta \mathrm{S}^{\circ}\left(\mathrm{J} \mathrm{K}^{-1} \mathrm{~mol}^{-1}\right)$ & & 36.5 \\
\hline \multicolumn{3}{|l|}{ Release kinetics } \\
\hline \multirow[t]{2}{*}{ Models } & \multicolumn{2}{|c|}{ Determination coefficient } \\
\hline & $\mathrm{pH} 1.2$ & $\mathrm{pH} 7.4$ \\
\hline Zero-order model & 0.70 & 0.57 \\
\hline First order model & 0.94 & 0.98 \\
\hline Higuchi model & 0.80 & 0.90 \\
\hline Hixson-Crowell model & 0.88 & 0.94 \\
\hline Korsmeyer-peppas model & 0.90 & 0.90 \\
\hline
\end{tabular}

\subsubsection{Equilibrium modeling 3.2.2.2.1. Classic equilibrium models}

The equilibrium behaviours of the IBF loading reactions into $\mathrm{Fe}^{0} @ \mathrm{CH} / \mathrm{CS}$ were assessed considering the assumptions of Freundlich, Langmuir, and Dubinin-Radushkevich (D-R) isotherm models (Table.S1). The values of $\chi^{2}$, as well as $\mathrm{R}^{2}$, demonstrate higher agreement with the Langmuir equilibrium properties rather than the equilibrium behaviour of Freundlich isotherm (Fig. 5A; Table.1). Such fitting findings suggested monolayer loading of the IBF ions on the surface of Fe0@CH/CS by the numerous homogeneously 
distributed active loading receptors [24]. Moreover, the reported values of the RL fitting parameter $(<1)$ displays the favourable loading process of the IBF ions into $\mathrm{Fe}^{0} @ \mathrm{CH} / \mathrm{CS}$ with a theoretical $\mathrm{Q}_{\max }$ of 540 $\mathrm{mg} / \mathrm{g}$ (Table.1). The fitting parameters of the D-R model as the Gaussian energy are of valuable indications about the properties of the IBF loading process into Fe ${ }^{0} @ \mathrm{CH} / \mathrm{CS}$ (Fig. 5A; Table.1) [37, 38]. The value of Gaussian energy $(6.45 \mathrm{KJ} / \mathrm{mol})$ suggested the physisorption of IBF ions by the active groups of $\mathrm{Fe}^{0} @ \mathrm{CH} / \mathrm{CS}$ which is in agreement with the kinetic findings (Table.1) [34].

\subsection{Advanced equilibrium studies}

To make a deep illustration about the IBF loading process into Fe ${ }^{0} @ \mathrm{CH} / \mathrm{CS}$, an advanced equilibrium model (Monolayer model of one energy) based on the statistic physics theory was studied the nonlinear fitting process with the equation of the model (Fig. 5B). The addressed fitting parameters are the number of loaded IBF ions per each receptor site ( $\mathrm{n})$, the present active loading receptor density (Nm), the IBF loading capacity of $\mathrm{Fe}^{0} @ \mathrm{CH} / \mathrm{CS}$ at the saturation state $\left(\mathrm{Q}_{\mathrm{sat}}\right)$, and the IBF loading energy $(\Delta \mathrm{E})$ (Table.1). Based on the value of the $n$ parameter (2.18), the IBF molecules were loaded into the receptors of $\mathrm{Fe}^{0} @ \mathrm{CH} / \mathrm{CS}$ as two or three ions per receptor. Moreover, this value suggested the loading of IBF in vertical/non-parallel orientation on the surface of $\mathrm{Fe}^{0} @ \mathrm{CH} / \mathrm{CS}$ by a multi-molecular mechanism $[39,40]$. The active loading receptors density $(\mathrm{Nm})$ of $\mathrm{Fe}^{0} @ \mathrm{CH} / \mathrm{CS}$ during the loading of IBF ions is $252.2 \mathrm{mg} / \mathrm{g}$ and the loading capacity of the composite at saturation $\left(Q_{\text {sat }}\right)$ is $553 \mathrm{mg} / \mathrm{g}$. Such equilibrium findings demonstrate the significance of $\mathrm{Fe}^{0} @ \mathrm{CH} / \mathrm{CS}$ as a carrier for IBF drugs with remarkable loading capacity.

The value of IBF loading energy into Fe $\mathrm{B}^{0} @ \mathrm{CH} / \mathrm{CS}$ carrier was estimated according to Eq. 4 in which the presented symbol donate the IBF loading energy $(\Delta \mathrm{E})$, gas constant $(\mathrm{R})$, temperature $(T)$, the solubility of IBF (S), and concentration of dissolved IBF at the half-saturation state (C).

$$
\Delta E=R \ln \left(\frac{S}{C}\right)(6)
$$

The value of IBF loading energy is $4.81 \mathrm{~kJ} / \mathrm{mol}$ and within the identified limit of physical mechanisms including hydrogen bonding $(<30 \mathrm{~kJ} / \mathrm{mol})$, van der Waals forces $(4-10 \mathrm{~kJ} / \mathrm{mol})$, and dipole bonding forces $(2-29 \mathrm{~kJ} / \mathrm{mol})[40]$.

\subsubsection{Thermodynamic properties}

The thermodynamic functions of the IBF loading reactions by $\mathrm{Fe}^{0} @ \mathrm{CH} / \mathrm{CS}$ were studied considering the experimental temperature range from $20^{\circ} \mathrm{C}$ up to $60^{\circ} \mathrm{C}$. The other affecting variables were fixed at $\mathrm{pH} 6$, $20 \mathrm{mg}$ as carrier dosage, $24 \mathrm{~h}$ as loading interval, $400 \mathrm{mg} / \mathrm{L}$ as IBF concentration, and $50 \mathrm{~mL}$ as IBF solution volume. The values of both entropy $\left(\Delta S^{\circ}\right)$ and enthalpy $\left(\Delta H^{\circ}\right)$ were obtained as fitting parameters for the linear regression fitting with Van't Hof equation (Eq. 4) (Fig. 6). However, the values of 
Gibbs free energy $\left(\Delta G^{\circ}\right)$ at the experimentally studied loading temperature were calculated based on Eq. 3 (Table.1) [33]:

$$
\begin{aligned}
\operatorname{In}\left(K_{C}\right) & =\frac{\Delta S^{o}}{R}-\frac{\Delta H^{o}}{R T}(3) \\
\Delta G^{0} & =-\operatorname{RTInK}_{C}(4)
\end{aligned}
$$

The calculated $\Delta \mathrm{G}^{\circ}$ values within the temperature range from $293 \mathrm{~K}$ up to $33 \mathrm{~K}$ are of negative signs which display the spontaneous and favorable loading of IBF into Fe ${ }^{0} @ \mathrm{CH} / \mathrm{CS}$ as a carrier (Table.1). Additionally, the estimated value of $\Delta \mathrm{H}^{\circ}$ as a fitting parameter with a negative sign confirms the exothermic properties of the occurred reactions during the loading of IBF into Fe $\mathrm{E}^{0} \mathrm{CH} / \mathrm{CS}$ (Table.1). The estimated positively signed value of $\Delta S^{\circ}$ display considerable enhancement in the randomness of the IBF loading reactions as a function of the tested temperature.

\subsection{In-vitro release profiles}

The release properties of IBF from Fe $\mathrm{e}^{0} @ \mathrm{CH} / \mathrm{CS}$ were studied considering two release buffers (gastric fluid $(\mathrm{pH}$ 1.2) and intestinal fluid ( $\mathrm{pH}$ 7.4)) (Fig. 7A). The recognized IBF release rates within the two buffers are of fats properties during the initial intervals of the release process (Fig. 7A). After that, the IBF diffusion rates shows remarkable slow behaviors, and the recognized rates declined significantly until attending an equilibration state of fixed IBF release values by the ending of the release interval (Fig. 7A). The detected fast IBF release rates with starting the process are credited to the abrupt and significant desorption of the drug ions from the surficial receptors of $\mathrm{Fe}^{0} @ \mathrm{CH} / \mathrm{CS}$ [41]. After that, the release of IBF became restricted to the loaded ions which are of strong bonds with the active groups of $\mathrm{Fe}^{0} @ \mathrm{CH} / \mathrm{CS}$ in addition to the deep entrapped ions within the matrix of $\mathrm{CH} / \mathrm{CS}$ matrix $[12,42]$.

Within the studied gastric buffer ( $\mathrm{pH}$ 1.2), the release of IBF ions continued up to 260 min without attending the complete diffusion of the loaded drug dosage (Fig. 7A). $50 \%$ of the loaded IBF dosage was diffused after $30 \mathrm{~h}$ and $91 \%$ as the maximum diffused percentage was detected after $260 \mathrm{~min}$ (Fig. 7A). Within the intestinal buffer $(\mathrm{pH} 7.4)$, the release of IBF from Fe ${ }^{0} @ \mathrm{CH} / \mathrm{CS}$ is of faster properties than the gastric buffer (Fig. 7A). 50\% and 95\% of the IBF dosage were diffused from Fe $0 \mathrm{CH} / \mathrm{CS}$ after $20 \mathrm{~h}$ and $100 \mathrm{~h}$, respectively, and the complete IBF diffusion (100\%) was detected after $180 \mathrm{~h}$ (Fig. 7A). The recognized fast IBF release properties from Fe $\mathrm{e}^{0} @ \mathrm{CH} / \mathrm{CS}$ at the basic buffer (intestinal $(\mathrm{pH} 7.4)$ ) was assigned to the high solubility of IBF at this $\mathrm{pH}$ as compared to the acidic $\mathrm{pH}$ values [43]. The high solubility of IBF induces the migration and diffusion of the structure of $\mathrm{Fe}^{0} @ \mathrm{CH} / \mathrm{CS}$ into the release buffer. On the other hand, at the acidic $\mathrm{pH}$ value $(\mathrm{pH} 1.2)$, the IBF is of poor solubility and accumulates in its molecular form which reduces the release efficiency $[8,43]$.

Generally, the synthetic carriers that are of controlled release properties were recommended. For some cases, the synthetic carriers that are of abrupt IBF release properties are highly effective to liberate the loaded dosage within a short interval according to the required therapeutic value. In other cases, 
developing carriers of slow and continuous IBF release properties is preferred to keep the drug at the recommended limit for long intervals $[33,44]$. Therefore, the green synthesized Fe $\mathrm{C}^{0} \mathrm{CH} / \mathrm{CS}$ is a valuable structure to be used as a delivery system of controlled and enhanced IBF loading and release properties based on the experimental conditions.

\subsection{Release kinetics}

The IBF release kinetics from Fe $\mathrm{e}^{0} @ \mathrm{CH} / \mathrm{CS}$ reflects the affecting mechanism during the release reactions. The kinetic properties were studied based on the recognized linear fitting results with Zero-order (Z-O) (Eq. 5), First-order (F-O) (Eq. 6), Higuchi (H-U) (Eq. 7), Hixson-Crowell (H-C) (Eq. 8), and KorsmeyerPeppas (K-P) models (Eq. 9) [12].

$$
\begin{gathered}
W_{t}-W_{0}=K_{0} \cdot \mathrm{t}(5) \\
\ln \left(W_{\infty} / W_{t}\right)=K_{1} \cdot t(6) \\
W_{t}=K_{h} t^{1 / 2}(7) \\
W_{o}^{1 / 3}-W_{t}^{1 / 3}=K_{H C} \mathrm{t}(8) \\
W_{t} / W_{\infty}=K_{p} t^{n}(9)
\end{gathered}
$$

The kinetic properties of the Zero-order (Z-O) model involved the release of IBF according to constant rate without considerable influence for the IBF dosage as a loaded drug [45]. The release kinetics that follows the First-order ( $\mathrm{F}-\mathrm{O}$ ) properties assumes a significant effect for the loaded IBF dosage during the release reactions [43]. The release of IBF according to the Higuchi $(\mathrm{H}-\mathrm{G})$ kinetic demonstrates a controlling effect for diffusion processes according to six parameters during the reaction. The controlling parameter are (1) the loading of IBF at a concentration higher than the released concentration, (2) there is only one direction along it the IBF drug can be diffused, (3) the IBF diffusion is constant during the process, (4) the actual diameter of IBF grains should be smaller than the actual thickness of $\mathrm{Fe}^{0} @ \mathrm{CH} / \mathrm{CS}$ grains, (5) the detected solubility and swelling value of $\mathrm{Fe}^{0} @ \mathrm{CH} / \mathrm{CS}$ are of significant effect on the IBF release rate, and (6) the loaded IBF as a drug is remarkable sink properties [32, 45]. The release of IBF based on the HixsonCrowell $(\mathrm{H}-\mathrm{C})$ model suggests an essential effect for the erosion mechanisms during the release processes considering the significant impact of both the $\mathrm{Fe}^{0} @ \mathrm{CH} / \mathrm{CS}$ diameter and its surface area [46]. The kinetic hypothesis of the K-P model suggested the dominant effects of both diffusion and erosion mechanisms during eth IBF release process from Fe0@CH/CS [47].

Based on the estimated fitting degrees, the IBF release results are of strong agreement with the First-order model (F-O) as compared to the Zero-order model (Z-O) (Fig. 7B and C; Table.1). Therefore, the IBF release behavior depends essentially on the loaded concentration of IBF. The recognized IBF results also are of significant agreement with both the Higuchi model and Hixson-Crowell release kinetic models (Fg.7D and E; Table.1). This suggested the release of IBF from Fe $\mathrm{F}^{0} @ \mathrm{CH} / \mathrm{CS}$ into the studied buffers by both diffusion 
and erosion mechanisms. Such findings were supported by the detected excellent fitting with KorsmeyerPeppas (K-P) model (Fig. 7F). The obtained diffusion exponent as fitting parameter ((0.58 (pH 1.2) and $0.48(\mathrm{pH} 7.4))$ declared the release of IBF by anomalous release behavior (non-Fickian transport reaction) (Table.1). This also confirms the operation of erosion and diffusion mechanisms during the IBF release processes from Fe $@ \mathrm{CH} / \mathrm{CS}$ carrier [33].

\subsection{Cytotoxicity properties}

The cytotoxicity effects of Fe ${ }^{0} @ \mathrm{CH} / \mathrm{CS}$ and IBF-loaded Fe0@CH/CS on the Human bronchial epithelial cells were assessed considering the tested dosages from $100 \mu \mathrm{g} / \mathrm{mL}$ up to $300 \mu \mathrm{g} / \mathrm{mL}$. Considering the determined values of cell viability based on the performed MTT assay tests, the synthetic $\mathrm{Fe}^{0} @ \mathrm{CH} / \mathrm{CS}$ particles, as well as the IBF-loaded product, are of remarkable biocompatibility and safety be used as a delivery system. The measured cell viability percentages using $300 \mu \mathrm{g} / \mathrm{mL}$ as the maximum dosages of $\mathrm{Fe}^{0} @ \mathrm{CH} / \mathrm{CS}$ and IBF-loaded Fe ${ }^{0} @ \mathrm{CH} / \mathrm{CS}$ are $92.7 \%$ and $89.2 \%$, respectively.

\section{Conclusion}

The synthetic Fe $\mathrm{e}^{0} \mathrm{CH} / \mathrm{CS}$ green nanostructure was synthesized as a potential carrier for IBF drug with a loading capacity of $553 \mathrm{mg} / \mathrm{g}$. The IBF loading process is of homogenous, physisorption, and monolayer properties based on the representative equilibrium (Langmuir) and kinetic (Pseudo-First order) models. Considering the advanced isotherm studies (Monolayer model of one energy), the IBF drug was loaded in a vertical orientation as two or three ions per loading site by a multi-molecular process. The IBF loading energy $(4.81 \mathrm{~kJ} / \mathrm{mol})$ donated physical loading mechanisms (Van-der Waals forces and/or hydrogen bonding). The synthetic Fe $0 \mathrm{CH} / \mathrm{CS}$ structure exhibits continued and slow-release behavior for about $260 \mathrm{~h}$ at $\mathrm{pH} 1.2$ and $180 \mathrm{~h}$ at $\mathrm{pH}$ 7.4. The IBF release kinetics and the obtained diffusion exponent $(0.58$ $(\mathrm{pH} 1.2)$ and $0.48(\mathrm{pH} \mathrm{7.4)})$ reflects complex diffusion/erosion release mechanisms. Both $\mathrm{Fe}^{0} @ \mathrm{CH} / \mathrm{CS}$ (300 $\mu \mathrm{g} \mathrm{mL}^{-1}$; cell-viability $\left.92.7 \%\right)$ and IBF loaded Fe ${ }^{0} @ \mathrm{CH} / \mathrm{CS}\left(300 \mu \mathrm{g} \mathrm{mL}^{-1}\right.$; cell-viability $\left.89.2 \%\right)$ are of safe effects on the human bronchial epithelial cells.

\section{Declarations}

\section{ACKNOWLEDGMENT}

The authors acknowledge Researchers Supporting Project number (RSP-2021/149), King Saud University, Riyadh, Saudi Arabia.

\section{Ethical Approval}

The manuscript does not include experimental studies on any animal or human data

\section{Consent to Participate}

Not applicable 


\section{Consent to Publish}

Not applicable

\section{Authors Contributions}

The authors contribute equally in preparing the material, designing the experimental section, interpreting the results, and writing the manuscript

\section{Competing Interests}

The authors declare that there is no conflict in interest

\section{References}

1. L.D.O. Macedo, E.J. Barbosa, R. Löbenberg, N.A. Bou-Chacra, Eur. J. Pharm. Sci. 105654 (2020)

2. Q. Chen, L. Di, Y. Zhang, N. Li, J. Ethnopharmacol. 259, 112948 (2020)

3. S.M. Mahgoub, M.R. Shehata, F.L.A. El-Ela, A. Farghali, A. Zaher, R.K. Mahmoud, RSC Adv. 10(46), 27633-27651 (2020)

4. R. Tsivkovskii, M. Sabet, Z. Tarazi, D.C. Griffith, O. Lomovskaya, M.N. Dudley, FEMS Microbiol. Immunol. 61(2), 141-146 (2011)

5. Y. Wang, J. Ke, K. Gou, Y. Guo, X. Xu, S. Li, H. Li, Microporous Mesoporous Mater. 294, 109896 (2020)

6. A. Celebioglu, T. Uyar, Mol. Pharm. 16(10), 4387-4398 (2019)

7. S. Javanbakht, P. Nezhad-Mokhtari, A. Shaabani, N. Arsalani, M. Ghorbani, Mater. Sci. Eng. C 96, 302-309 (2019)

8. M.R. Abukhadra, N.M. Refay, A. Nadeem, A.M. El-Sherbeeny, K.E. Ibrahim, Int. J. Biol. Macromol. 156, 537-547 (2020)

9. S.M. Ibrahim, M.N. Bin Jumah, S.I. Othman, R.S. Alruhaimi, N. Al-Khalawi, Y.F. Salama, A.A. Allam, M.R. Abukhadra, ACS Omega 6, 13406-13416 (2021)

10. C. Lu, Y. Xiao, Y. Liu, F. Sun, Y. Qiu, H. Mu, J. Duan, Carbohydr. Polym. 229, 115479 (2020)

11. Z. Kuang, G. Dai, R. Wan, D. Zhang, C. Zhao, C. Chen, J. Li, H. Gu, W. Huang, Genes \& diseases 8(2), 193-202 (2021)

12. L. Tian, M.R. Abukhadra, A.S. Mohamed, A. Nadeem, S.F. Ahmad, K.E. Ibrahim, ACS Omega. 5(30), 19165-19173 (2020)

13. S. Safi, F. Karimzadeh, S. Labbaf, Sci. Eng. C 92, 712-719 (2018)

14. J. Jacob, J.T. Haponiuk, S. Thomas, S. Gopi, Mater. Chem. today 9, 43-55 (2018)

15. Y. Jiang, M.R. Abukhadra, N.M. Refay, M.F. Sharaf, M.A. El-Meligy, E.M. Awwad, React. Funct. Polym. 154,104675 (2020)

16. T.C. Mokhena, M.J. John, Cellulose. 27(3), 1149-1194 (2020) 
17. M.R. Abukhadra, A. Al-Hammadi, A.M. El-Sherbeeny, M.A. Salam, M.A. El-Meligy, E.M. Awwad, M. Luqman, Carbohydr. Polym. 252, 117163 (2021)

18. A.M. Saad, M.R. Abukhadra, S.A.K. Ahmed, A.M. El-Zanaty, A.H. Mady, M.A. Betiha, J.J. Shim, A.M. Rabie, Environ Manage. 258, 110043 (2020)

19. M. Pooresmaeil, S. Javanbakht, S.B. Nia, H. Namazi, Colloids Surf. A: Physicochem Eng. Aspects 594, $124662(2020)$

20. J.N. Putro, S.P. Santoso, S. Ismadji, Y.H. Ju, Microporous Mesoporous Mater. 246, 166-177 (2017)

21. H.P.S. Abdul Khalil, A.S. Adnan, E.B. Yahya, N.G. Olaiya, S. Safrida, M. Hossain, V. Balakrishnan, D.A. Gopakumar, C.K. Abdullah, A.A. Oyekanmi, D. Pasquini, Polym. 12(8), 1759 (2020)

22. Y. Chen, L. Zhang, C. Mei, Y. Li, G. Duan, S. Agarwal, A. Greiner, C. Ma, S. Jiang, ACS Appl. Mater. Int. 12(31), 35513-35522 (2020)

23. M.A. Khalilzadeh, S. Tajik, H. Beitollahi, R.A. Venditti, Ind. Eng. Chem. Res. 59(10), 4219-4228 (2020)

24. M.R. Abukhadra, A.M. El-Sherbeeny, M.A. El-Meligy, M. Luqman, J. Biol. Macromol. 167, 335-344 (2020)

25. Y. Li, Y. Zhang, Q. Jing, Y. Lin, Catalysts. 10(4), 412 (2020)

26. Y. Zhang, L. Zhao, Y. Yang, P. Sun, Int. J. Environ. Research public. health 17(4), 1324 (2020)

27. F.M. Dardir, E.A. Ahmed, M.F. Soliman, S.I. Othman, A.A. Allam, M.A. Alwail, M.R. Abukhadra, Colloids Surf. A: Physicochem Eng. Aspects 624, 126805 (2021)

28. W. Chen, H. He, H. Zhu, M. Cheng, Y. Li, S. Wang, Polym. 10(6), 592 (2018)

29. M.R. Abukhadra, S.M. Ibrahim, M.T. Ashraf, J.S. Khim, A.A. Allam, J.S. Ajarem, H.S. Mahmoud, J. SolGel Sci. Technol. 100(1), 101-114 (2021)

30. L. Gao, J. Sun, L. Zhang, J. Wang, B. Ren, Mater. Chem. Phys. 135(2-3), 786-797 (2012)

31. I.A. Sogias, A.C. Williams, V.V. Khutoryanskiy, Int. J. Pharm. 436(1-2), 602-610 (2012)

32. M. Mostafa, M.A. El-Meligy, M. Sharaf, A.T. Soliman, M.R. AbuKhadra, Int. J. Biol. Macromol. 179, 206-216 (2021)

33. M.R. Abukhadra, N.M. Refay, A.M. El-Sherbeeny, A.M. Mostafa, M.A. Elmeligy, Int. J. Biol. Macromol. $141,721-731$ (2019)

34. M.A. Salam, M.R. Abukhadra, M. Mostafa, Environ. Sci. Pollut Res. 27(12), 13247-13260 (2020)

35. Y. Huang, S. Li, J. Chen, X. Zhang, Y. Chen, Appl. Sur Sci. 293, 160-168 (2014)

36. X. Li, D. Zhang, F. Sheng, H. Qing, Ecotoxicol. Environ. Saf. 147, 357-366 (2018)

37. M.V. Dinu, M.M. Lazar, E.S. Dragan, React. Funct. Polym. 116, 31-40 (2017)

38. E.S. Dragan, M.V. Dinu, ACS Appl. Mater. interfaces 10(24), 20499-20511 (2018)

39. X. Yang, J. Wang, A.M. El-Sherbeeny, A.A. Al-Hammadi, W.H. Park, M.R. Abukhadra, Chem. Eng. 431, $134312(2022)$

40. L. Sellaoui, H. Guedidi, L. Reinert, S. Knani, L. Duclaux, A.B. Lamine, RSC Adv. 6(15), 12363-12373 (2016) 
41. D. Tan, P. Yuan, F. Dong, H. He, S. Sun, Z. Liu, Appl. Clay Sci. 159, 102-106 (2018)

42. H.M. El-Zeiny, M.R. Abukhadra, O.M. Sayed, A.H. Osman, S.A. Ahmed, Physicochem Eng. Aspects 586, 124197 (2020)

43. J. Goscianska, A. Olejnik, I. Nowak, M. Marciniak, R. Pietrzak, Eur. J. Pharm. Biopharm. 94, 550-558 (2015)

44. L. Sun, Y. Chen, Y. Zhou, D. Guo, Y. Fan, F. Guo, Y. Zheng, W. Chen, Asian J. Pharm. 12(5), 418-423 (2017)

45. S.I. Othman, A.A. Allam, H. Al Fassam, G.M. Abu-Taweel, N. Altoom, M.R. Abukhadra, J. Inorg. Organomet Polym Mater. 2021, 1-15

46. M. Ge, W. Tang, M. Du, G. Liang, G. Hu, S.J. Alam, Euro. J. Pharma Sci. 130, 44-53 (2019)

47. H. El-Hamshary, M.H. El-Newehy, M. Moydeen Abdulhameed, A. El-Faham, A.S. Elsherbiny, Mater. Chem. Phys. 225, 122-132 (2019)

\section{Table}

Table S1 is not available with this version.

\section{Figures}




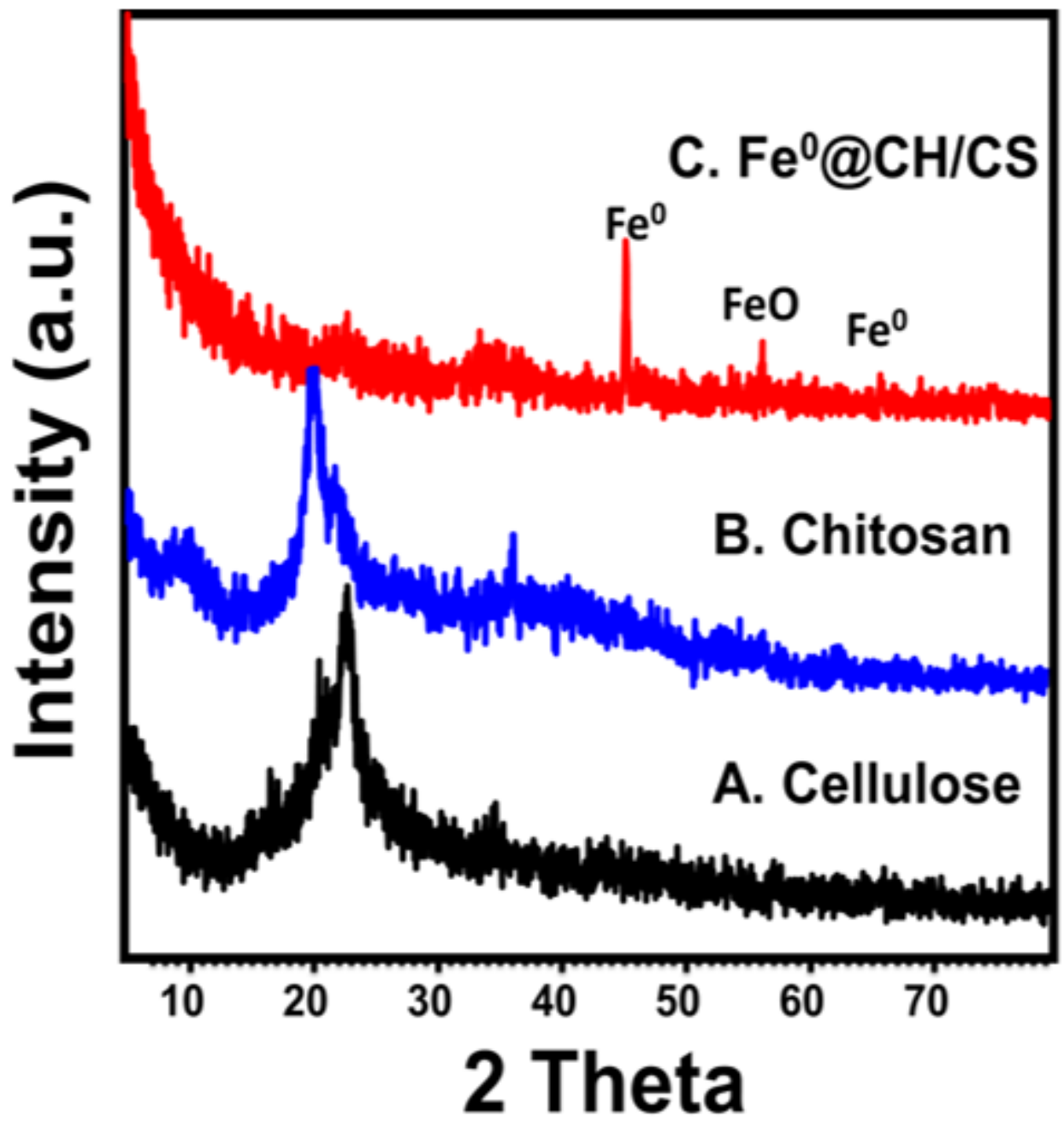

Figure 1

XRD pattern of of cellulose (A), chitosan (B), and synthetic Fe ${ }^{0} @ \mathrm{CH} / \mathrm{CS}(\mathrm{C})$ 


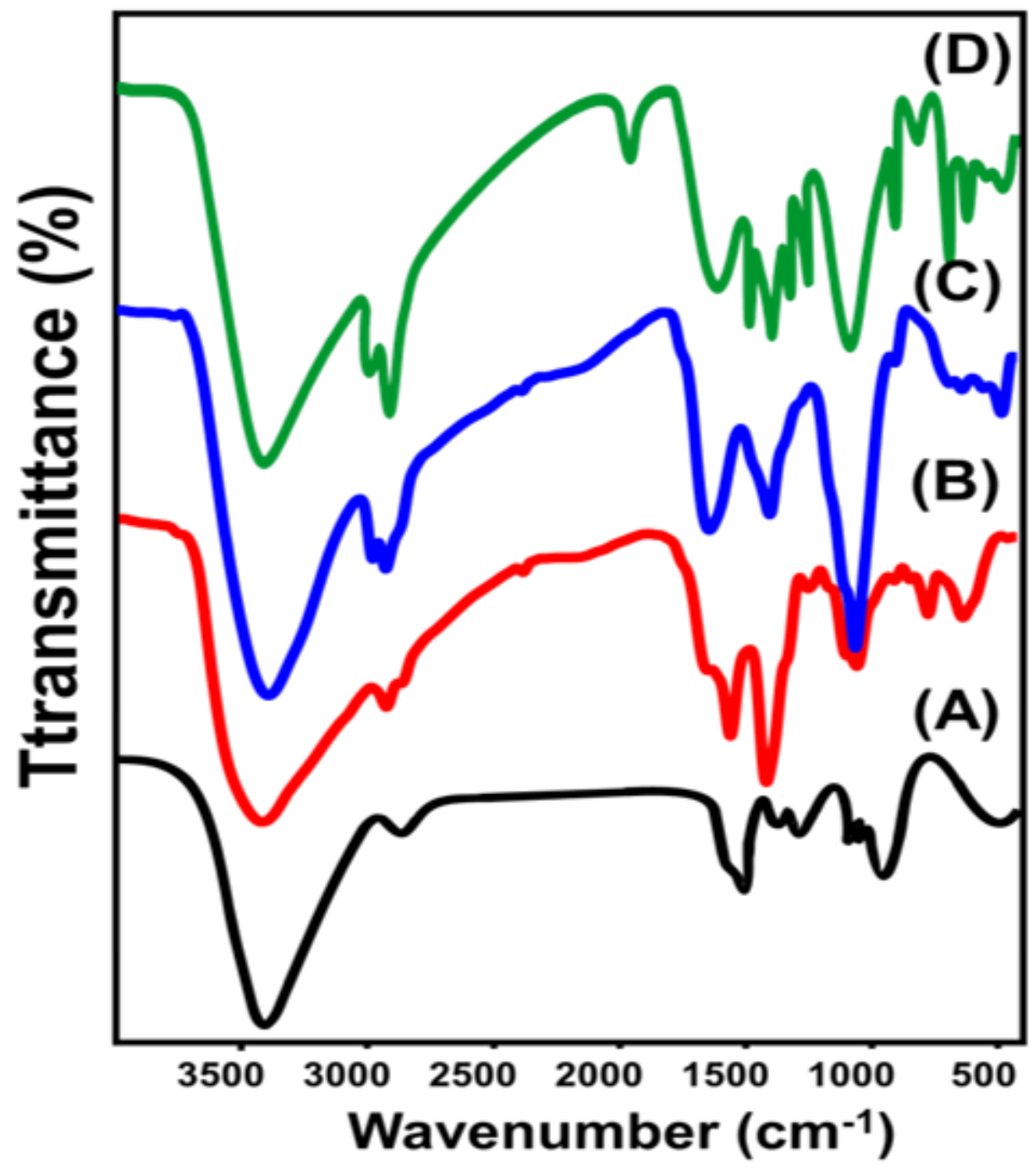

Figure 2

FT-IR spectra of cellulose (A), chitosan (B), synthetic Fe $\mathrm{e}^{0} @ \mathrm{CH} / \mathrm{CS}(\mathrm{C})$, and IBF loaded Fe $\mathrm{e}^{0} @ \mathrm{CH} / \mathrm{CS}$ (D) 

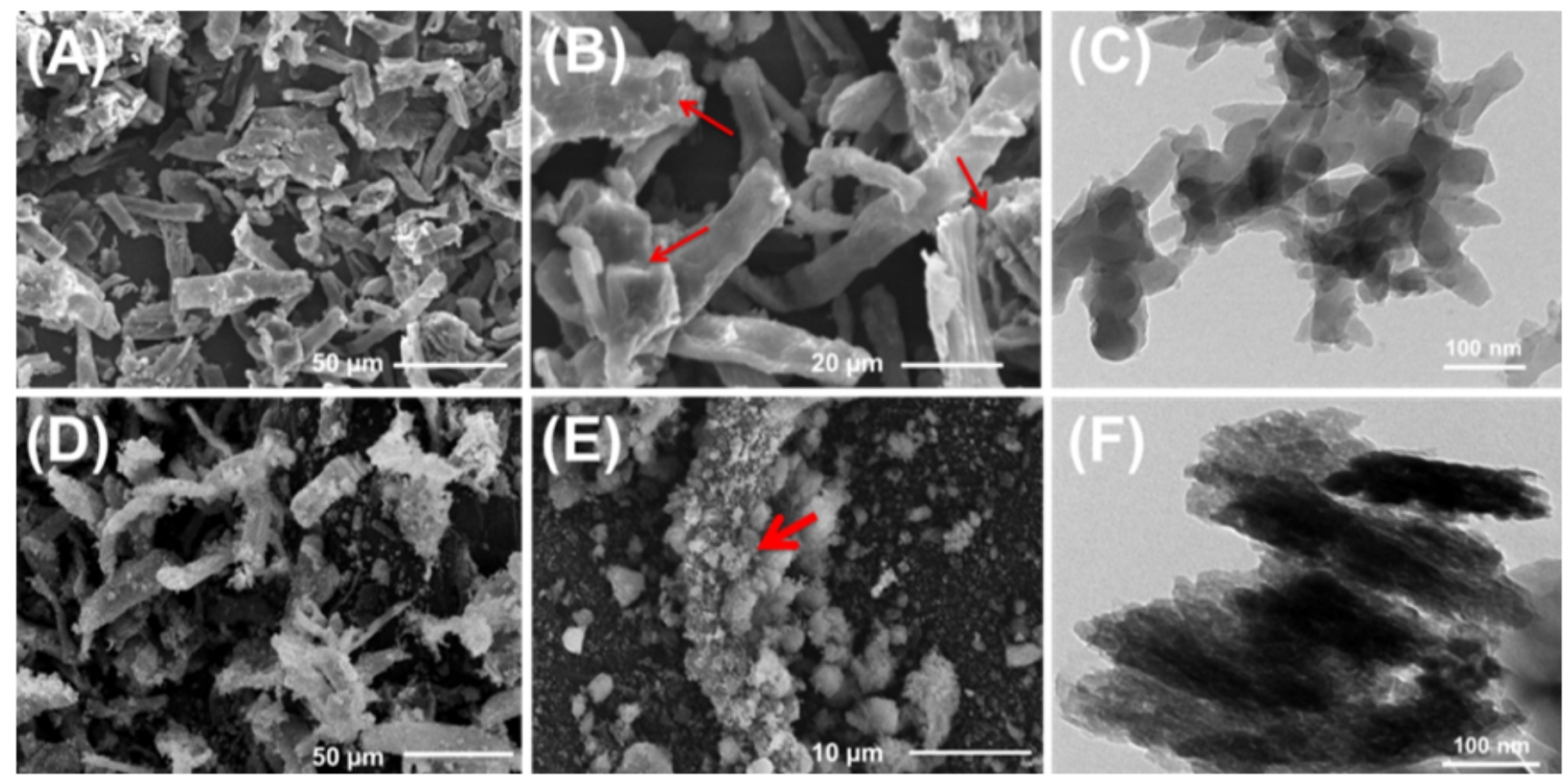

Figure 3

SEM of synthetic chitosan/cellulose composite (A and B), HRTEM of synthetic chitosan/cellulose composite (C), SEM of synthetic $\mathrm{Fe}^{0} @ \mathrm{CH} / \mathrm{CS}$ composite (D and E) (red arrow refers to the loaded $\mathrm{Fe}^{0}$ particles), and HRTEM of synthetic Fe ${ }^{0} @ \mathrm{CH} / \mathrm{CS}$ (F)
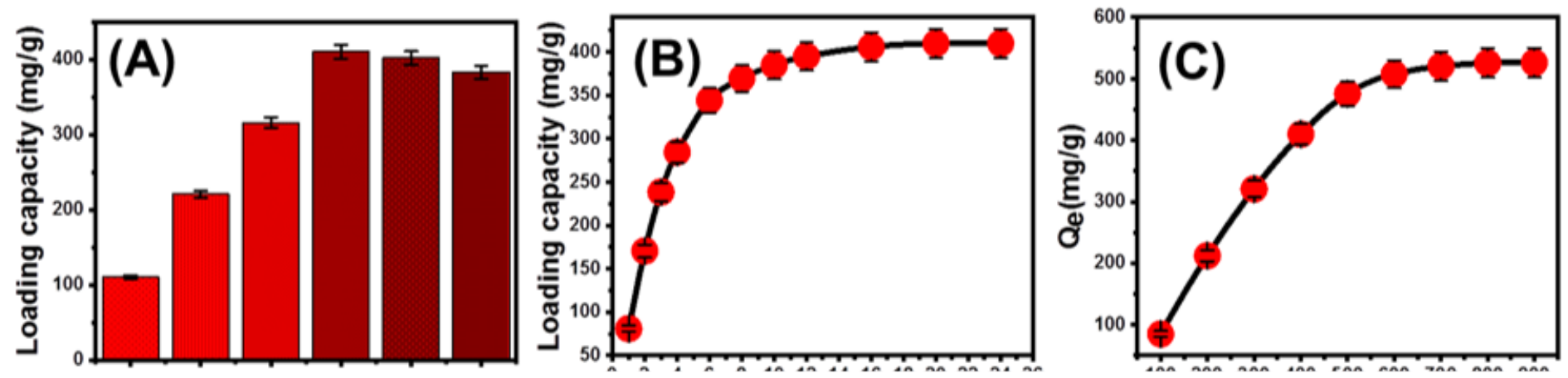

Figure 4 
Effect of $\mathrm{pH}$ values on the loading of IBF into $\mathrm{Fe}^{0} @ \mathrm{CH} / \mathrm{CS}(\mathrm{A})$, effect of time interval on the loading of IBF into $\mathrm{Fe}^{0} @ \mathrm{CH} / \mathrm{CS}(\mathrm{B})$, effect of IBF concentration on the loading capacity of $\mathrm{Fe}^{0} @ \mathrm{CH} / \mathrm{CS}$ (C), effect of the $\mathrm{Fe}^{0} @ \mathrm{CH} / \mathrm{CS}$ dosages on the loading efficiency of IBF (D), the Intra-Particle diffusion curve of IBF loading results $(E)$, and fitting of the IBF loading results with the different kinetic models $(F)$
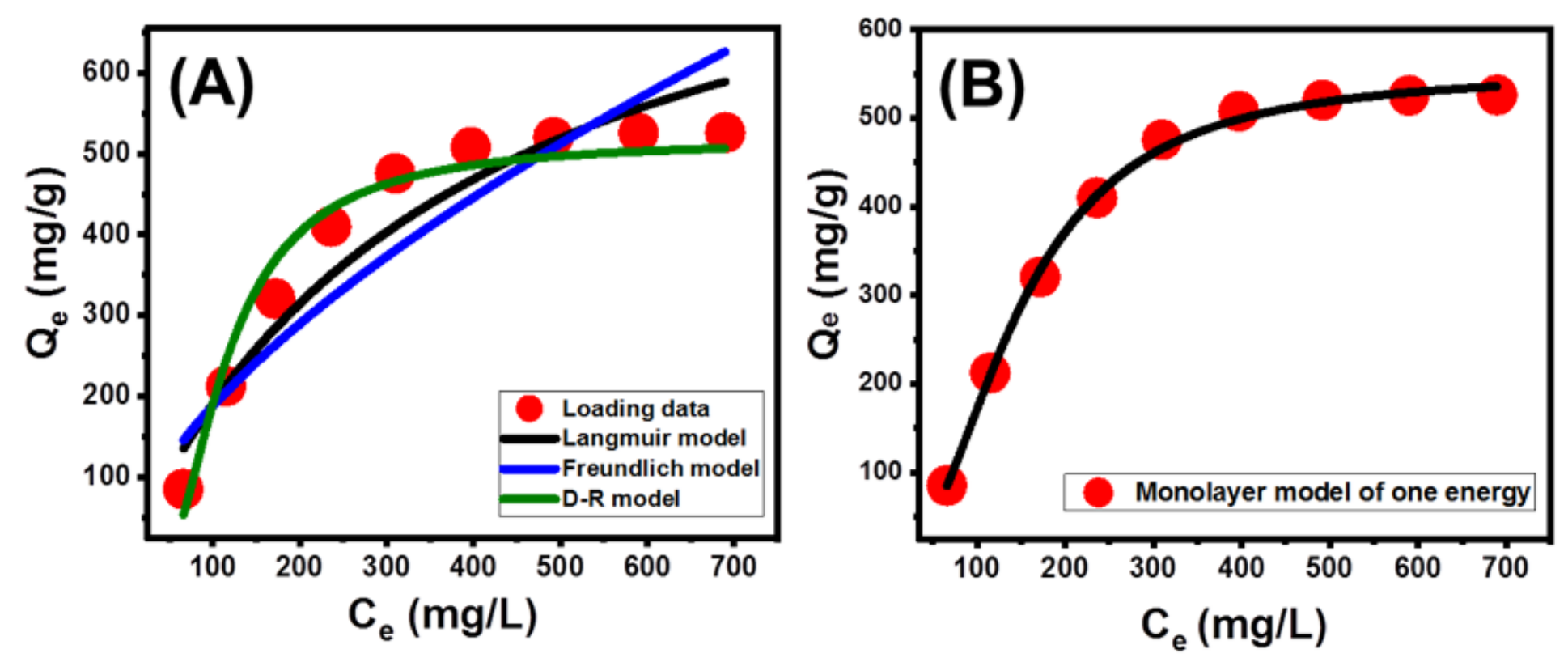

Figure 5

Fitting of the IBF loading results with the different equilibrium models (A), and fitting of the IBF loading results with Monolayer model o one energy (B) 


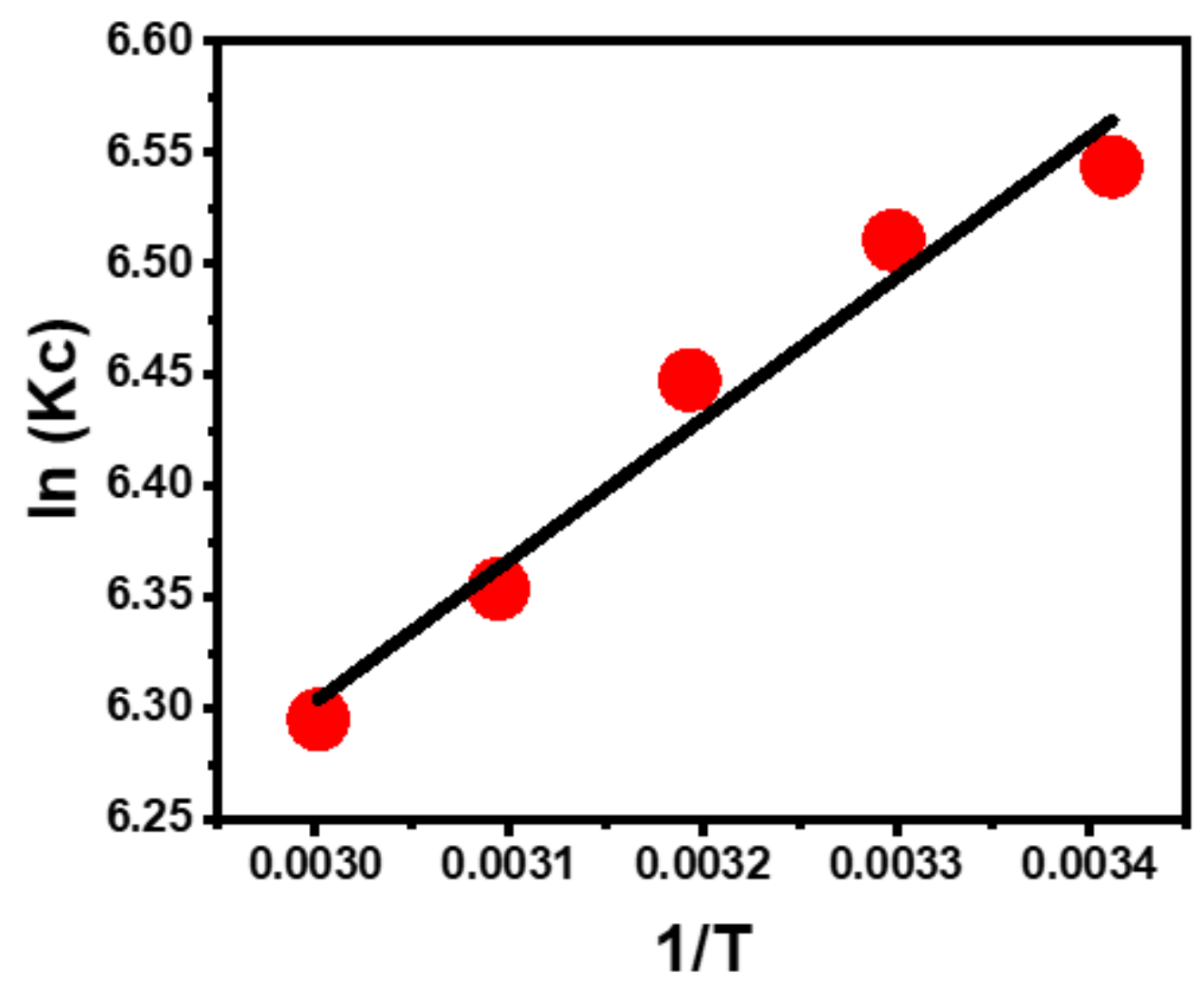

Figure 6

Fitting of the IBF loading results with Vant Hof equation
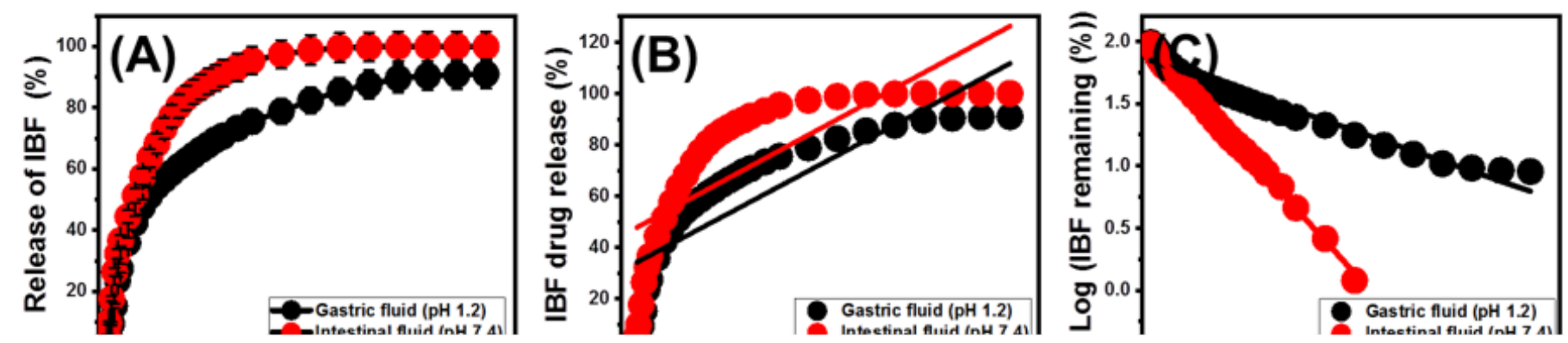


\section{Figure 7}

The release profiles of IBF from Fe $\mathrm{B}^{0} \mathrm{CH} / \mathrm{CS}(\mathrm{A})$, fitting of the IBF release results with Zero-order model (B), fitting of the IBF release results with First-order model (C), fitting of the IBF release results with Higuchi model (D), fitting of the IBF release results with Hixson-Crowell model (E), and fitting of the IBF release results with Korsmeyer-Peppas model (F) 